\title{
Storm Water and Contamination Control Efficiency Evaluation for Construction of a Neighborhood Project Using Low Impact Development
}

\author{
Bing Liu ${ }^{1}$, Gang Xie ${ }^{1}$, Yousheng Wang ${ }^{1}$, Xiaolin Yin ${ }^{1}$, Xiaoming Zhang ${ }^{1}$, Yang Zhao ${ }^{1, a}$ \\ ${ }^{1}$ State Key Lab of Simulation and Regulation of Water Cycle in River Basin, China Institute of Water Resources and Hydropower \\ Research, 10048, Chegongzhang West St. No. 20, Haidian District, Beijing, China
}

\begin{abstract}
Urban flooding and water pollution are urgent problems to be solved in urban development. The improvement of urban drainage and water quality in urban construction using ecological measures is an important research task. Low impact development (LID) is a new concept in soil and water conservation aimed at improving urban rainwater use and reducing non-point source pollution. This paper discusses the best management practices (BMPs) related to storm water and contamination control efficiency by comparing pre-development and post-development neighborhoods (both conventional and LID designs). The study area was Weatherford, Oklahoma, United States. The results showed that conventional design had the lowest total runoff but highest peak rate, infiltration trenches with rain barrels were more efficient than bioswales, and the use of LID design would reduce total runoff and peak rate significantly. However, LID design would increase construction and annual maintenance fees.
\end{abstract}

\section{Introduction}

With the rapid development of production and construction activities and the improvement of people's living standards, cities are facing environmental problems brought about by urbanization, such as water pollution, water stress, flood disasters, etc. ${ }^{[1]}$ The increase in urban hardened areas, the reduction of lake wetlands, and the filling and excavation of river channels have all caused serious urban internal defects. Due to the relative backwardness of infrastructure construction, the lack of basic research on the hydrodynamics of urban underlying surfaces, and the lack of urban soil and water conservation models, the phenomenon of relatively serious flood will still occur after heavy rains, and it will be difficult to achieve the expected results of implemented soil and water conservation measures ${ }^{[2]}$.

As early as the late $19^{\text {th }}$ century, researchers concerned about the impact of urban construction on runoff ${ }^{[3]}$. The increase in impervious areas not only increases total runoff and flood peak runoff, but also causes non-point source pollutants to accumulate on the hardened surface [4]. The low impact development (LID) concept was proposed in the mid-1980s based on the study of the bioretention pond in Prince George County, Maryland ${ }^{[5]}$. Unlike traditional stormwater control measures, LID reduces peak flow rates and runoff. In 2000, the US Environmental Protection Agency published a review of LID, and since then a large number of studies on LID have been carried out in the United States ${ }^{[6]}$. The Jordan Cove Urban Watershed Project in the United States has established a large LID experimental area in Waterford,
Connecticut, including 17 traditional soil and water conservation measures and 12 LID measures. A large number of experiments and comparative analyses were carried out. The main measures of LID are bioretention ponds, roof greening, permeable pavement, rainwater storage tanks, soil improvement, and three-box filtration.

At present, the most commonly used LID-based urban rainwater control prediction models include MIKE, developed by DHI, and SWMM (Storm Water Management Model), and developed by the US Department of Environmental Protection in the 1970s. Both of them are used to simulate rainwater and pollutant for urban pipeline water networks. Pitt ${ }^{[7]}$ established SLAMM (Source Loading and Management Model) for pollutant prediction. Monash University and the Australia Cooperative Research Centre for Catchment Hydrology built the MUSIC (Model for Urban Stormwater Improvement Conceptualisation), which is mainly used in Australia's urban drainage systems. P8-UCM, established by William and Walker, is mainly for analysis of urban stormwater pollutants ${ }^{[8]}$. Among these, MIKE and SWMM are the most widely used, though the models are more complicated than the others. IDEAL (Integrated Design, Evaluation, and Assessment of Loadings) was established by Barfield and Hayes ${ }^{[9]}$. The main purpose is to determine the effects of soil and water conservation measures in urban production and construction areas, incorporating improved best management practices (BMPs) from the SWMM model. The IDEAL model is similar to SWMM, but simpler to use and contains six major soil and water conservation measures. Although the types of soil and water conservation measures included

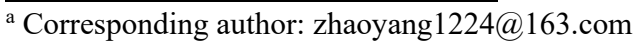


are based on US standards, the parameters can be adjusted to be more suitable for production and construction projects.

In this paper, the IDEAL model was used to design the LID for a new-construction residential area. One predevelopment model and three post-development models (one conventional and two LIDs) were built to compare the efficiency of different BMP combinations.

\section{Methodology}

\subsection{Site description}

The study site was located in the city of Weatherford, Oklahoma, United States (Figure 1). The new development is a 16.6-ha rectangular area, with a length of $494.7 \mathrm{~m}$ and a width of $335.3 \mathrm{~m}$. Field measurements were done in November to obtain the average slope $(1 \%)$ and the land use (wheat). The soil type (Pond Creek silt loam) was obtained from the Web Soil Survey. The above information was entered into the IDEAL model to calculate the total and peak runoffs.

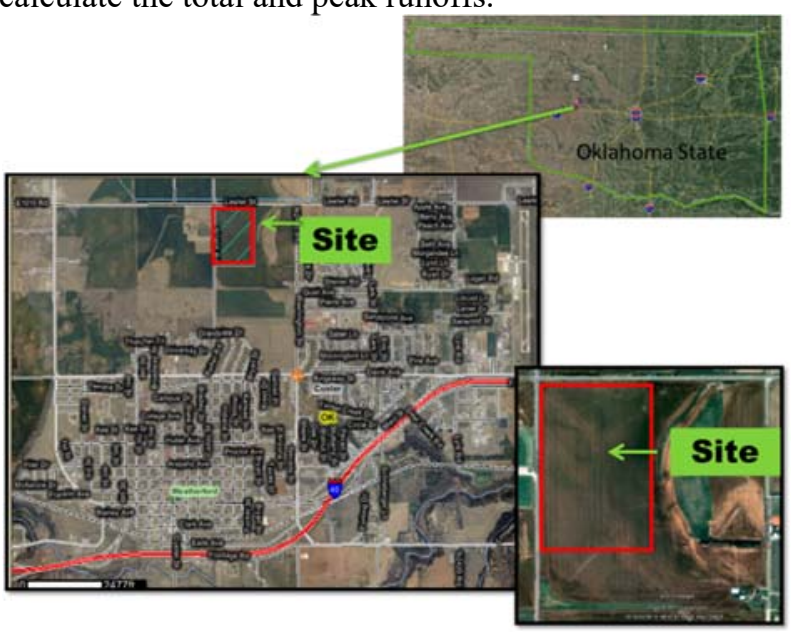

Figure 1. The location of the study site.

\subsection{Pre-development IDEAL model}

In the IDEAL model, the new development area was assumed to be pervious. Four kinds of information were required for the model: hydrologic information, sediment information, nutrient information and bacteria information.

For hydrologic parameters, the soil series was set as Fannin, as Pond Creek silt loam is not available in the IDEAL model; Fannin was the closest available soil type (with similar proportions of clay, silt, and sand). The curve number used was "Open spaces, lawns, parks etc.: Good condition, soil type B". For sediment information, the cover and practice factor chosen was "Flower bed: height of flower $=0.5 \mathrm{ft}$, cover percent 100 , mulch weighted area 0.1 , mulch percent 60 ". The nutrient information and bacteria information were "wooded" and "undisturbed wood", respectively.

The storm event we selected was a single storm for Southern Greenville, South Carolina. We selected a 25year, 24-hour storm, as there might be runoff from the adjacent land under these circumstances. Although our design is based on the 25-year, 24-hour storm, we also calculated the total and peak runoffs with a 2-year, 24hour storm and a 10-year, 24-hour storm.

\subsection{Post-development IDEAL model}

\subsubsection{Conventional Neighborhood Design}

The conventional neighborhood design was based on a typical Weatherford neighborhood, as shown in Figure 2. This design included 85 lots. Each lot covered 0.16 ha $\left(297.3 \mathrm{~m}^{2}\right.$ roof area, $81.8 \mathrm{~m}^{2}$ driveway, $32.5 \mathrm{~m}^{2}$ sidewalk, and $120.8 \mathrm{~m}^{2}$ yard). In this layout, only a dry detention pond ( $0.3 \mathrm{ha}, 4317.25 \mathrm{~m}^{3}$ storage) was used to store the rainwater. The IDEAL model layout is shown in Figure 3.

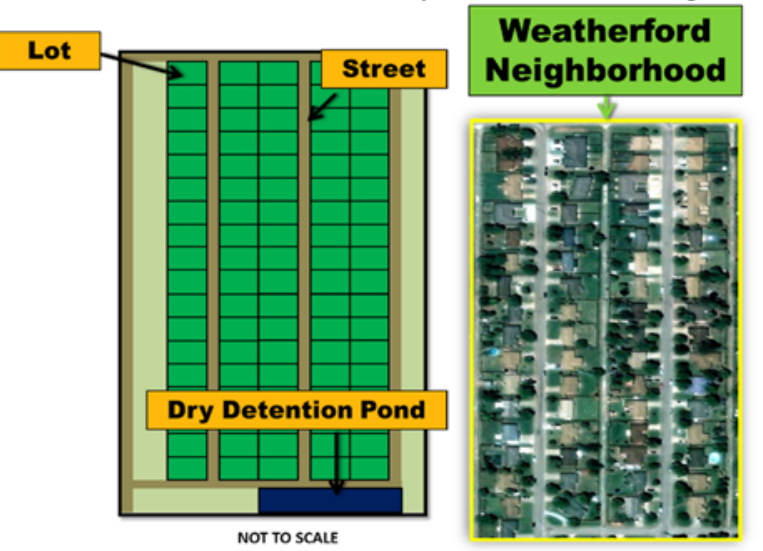

Figure 2. A conventional neighborhood layout for Weatherford, Oklahoma.

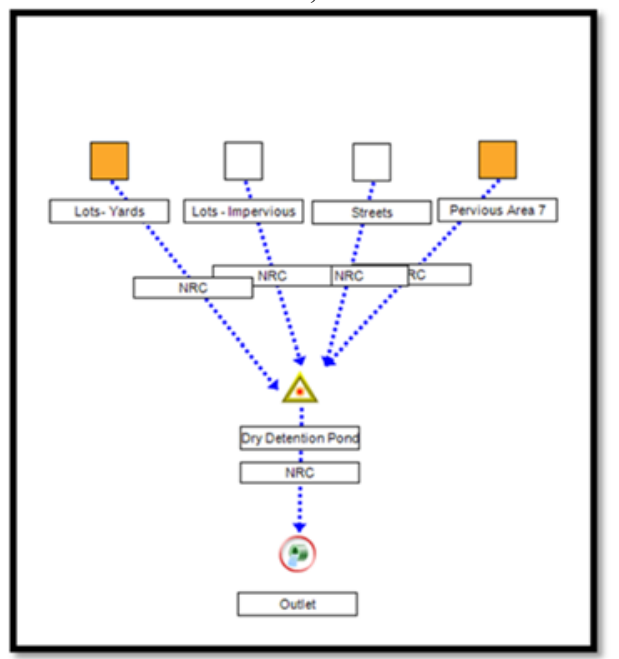

Figure 3. The conventional neighborhood IDEAL model.

\subsubsection{LID Neighborhood}

The LID neighborhood layout used the concept of cul-desacs, as this design best meets the needs of our low impact development. The layout of one cul-de-sac is shown in Figure 4. The cul-de-sac has a central area where the stormwater controls will be located. Around the central area, there will be eight lots. Between the lots and the central area is a one way street. The stormwater controls in the central area will capture the runoff from the cul-de- 
sac. The runoff that cannot be held will flow to the main street. Additional benefits are low total traffic and speed, sheltered from noise of the main thoroughfare.

In this project, we included 11 cul-de-sacs in the new developed area. The LID neighborhood layout is shown in Figure 5. The main street will run down the center between two rows of cul-de-sacs. Large stormwater controls will be located in the middle of the main street and will capture runoff from the cul-de-sacs and the main street. A common green space to be shared by the whole neighborhood was included. As a consequence, the average lot size was reduced; the roof size was the same as in the conventional neighborhood, but the lawn size was smaller. In the bottom right area, we included a recreation area. This area can be used as a playground, park, etc. If flooding does happen, the recreation area will be flooded first to protect the other parts of the neighborhood.

This design included 88 lots. Each lot took 0.1 ha, and the central treatment area was 0.08 ha.
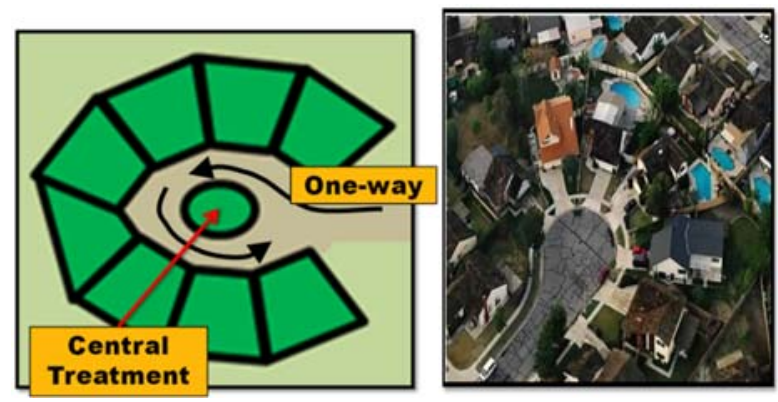

Figure 4. The layout of a typical cul-de-sac.

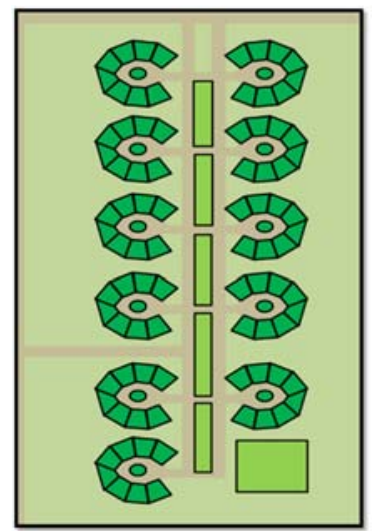

Figure 5. The LID neighborhood layout.

The first option for the LID neighborhood design (Option \#1) included 11 bioretention cells ( 0.08 ha each), 5 bioswales ( $71.7 \mathrm{~m} \times 4.7 \mathrm{~m}, 1.0 \mathrm{~m}$ deep), and 1 recreation area. The layout of this design is shown in Figure 6, and the IDEAL model layout is shown in Figure 7.

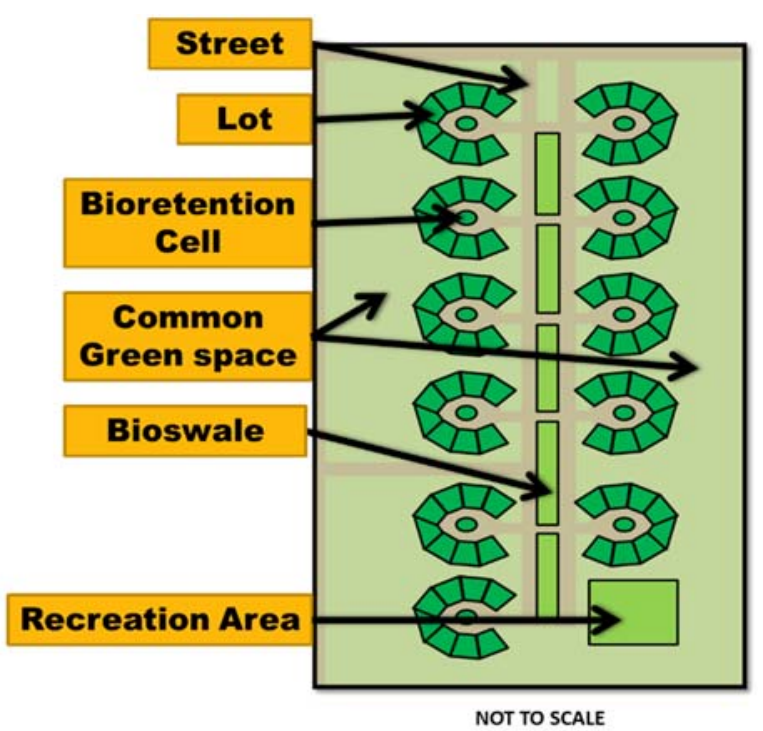

Figure 6. The LID neighborhood layout for Option \#1.

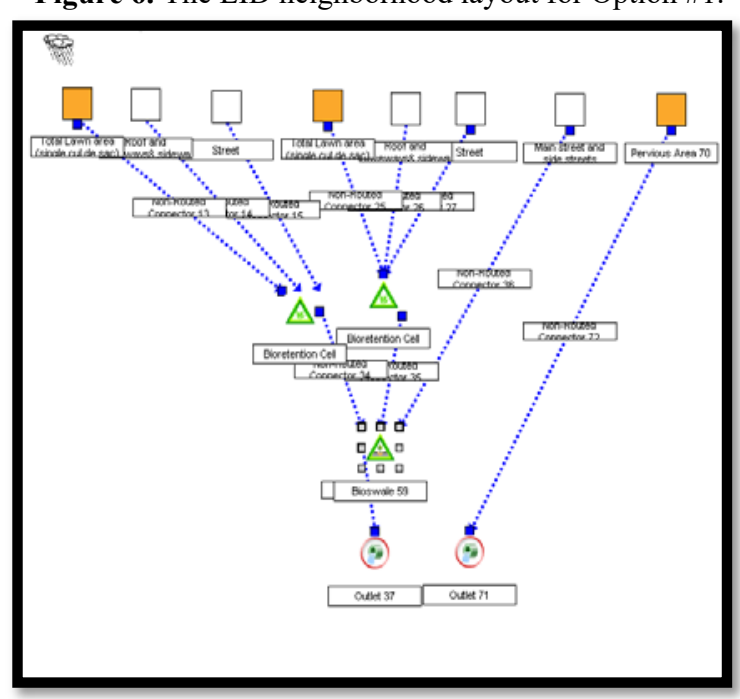

Figure 7. The LID neighborhood IDEAL model for Option \#1.

The second LID neighborhood design (Option \#2) included 11 bioretention cells ( 0.08 ha each), 5 infiltration trenches $\left(204.4 \mathrm{~m}^{2}, 1.3 \mathrm{~m}\right.$ deep), 88 rain barrels $(208.2 \mathrm{~L}$ each), and 1 recreation area. The layout of this design is shown in Figure 8 and the IDEAL model layout in Figure 9. 


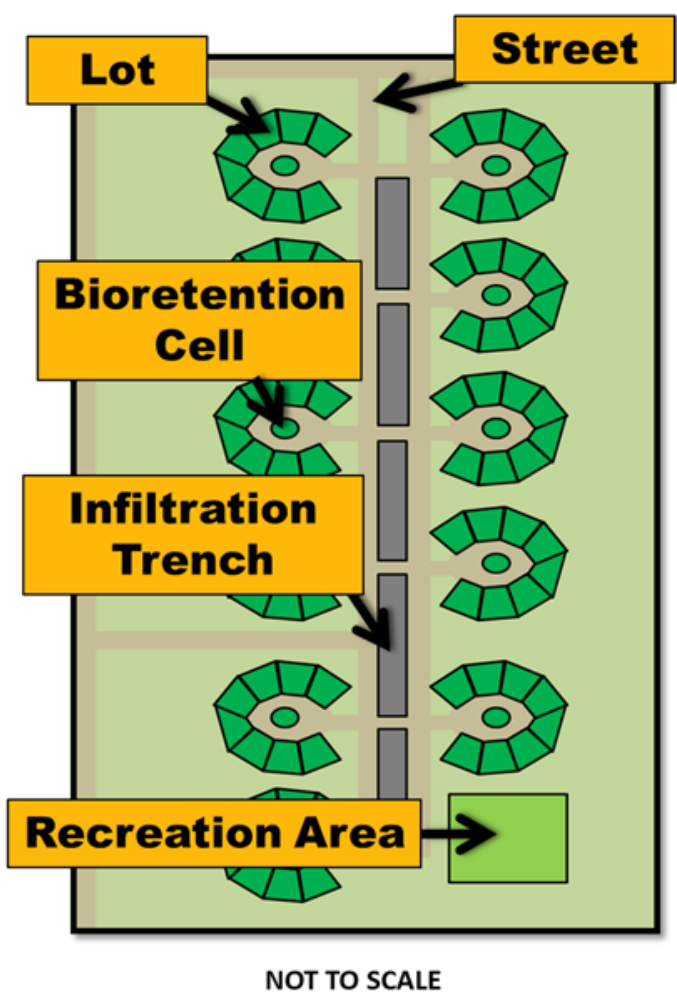

Figure 8. The LID neighborhood layout for Option \#2.

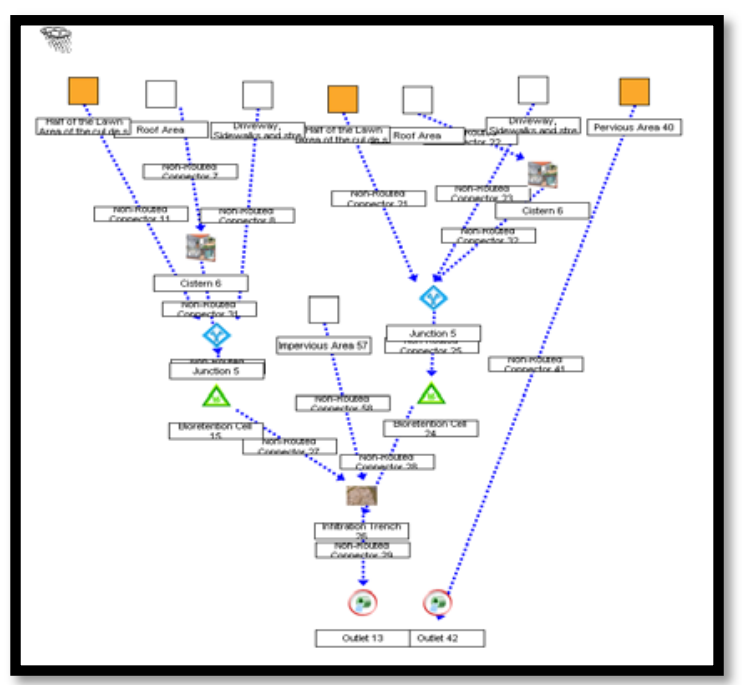

Figure 9. The LID neighborhood IDEAL model for Option \#2.

\section{Results and Discussion}

\subsection{Runoff Comparisons}

The total runoff and peak rate estimated by the IDEAL model for pre-development and post-development designs are given in Table 1. Both the conventional neighborhood layout and the LID neighborhood Option \#2 met the total runoff requirements. The conventional design had the lowest total runoff, followed by LID Option \#2. LID Option \#1 had the highest total runoff. These results indicate that a dry detention pond can reduce total runoff efficiently, and that infiltration trenches can reduce total runoff better than bioswales.
For the 2-year rainfall event, the conventional design had the lowest peak rate. However, for the 10- and 25year rainfall events, the conventional design had the highest peak rates. For all three rainfall events, the LID Option \#1 design had higher peak rates than the Option \#2 design. Only the LID Option \#2 design met the peak rate requirement for all three rainfall events. The results indicate that a dry detention pond would reduce peak rate significantly for small rainfall events, but has a reduced effect in more severe rainfall events. For 10- and 25-year rainfall events, the LID designs were more effective in reducing the peak rate than the conventional design, with the infiltration trench performing better than the bioswale.

Table 1. Runoff and peak rate results for pre-development and

\begin{tabular}{|c|c|c|c|c|}
\hline & Pre-Dev. & Conv. & LID \# 1 & LID \#2 \\
\hline \multicolumn{5}{|c|}{25 Year Rainfall Event } \\
\hline Total Runoff* & 10,485 & 8,511 & 16,036 & 10,238 \\
\hline Peak Rate** & 0.7 & 3.7 & 0.9 & 0.6 \\
\hline \multicolumn{5}{|c|}{10 Year Rainfall Event } \\
\hline Total Runoff & 6,908 & 4,687 & 11,225 & 6,538 \\
\hline Peak Rate & 0.4 & 1.3 & 0.7 & 0.4 \\
\hline \multicolumn{5}{|c|}{2 Year Rainfall Event } \\
\hline Total Runoff & 2,837 & 1,234 & 5,674 & 2,220 \\
\hline Peak Rate & 0.2 & 0.0 & 0.4 & 0.1 \\
\hline
\end{tabular}

\subsection{Cost Comparisons}

Table 2 gives the cost for each BMP and the total cost for the three post-development designs.

Table 2. Cost comparisons for post-development designs.

\begin{tabular}{|c|c|c|c|c|}
\hline & Goal & Conv. & LID \# 1 & LID \#2 \\
\hline $\begin{array}{c}\text { Total } \\
\text { Runoff* }\end{array}$ & 10,485 & 8,511 & 16,036 & 10,238 \\
\hline Peak Rate** & 0.7 & 3.7 & 0.9 & 0.6 \\
\hline $\begin{array}{c}\text { Estimated } \\
\text { Construction } \\
\text { Cost }\end{array}$ & - & $\$ 96,000$ & $\begin{array}{c}\mathrm{BRC}^{\mathrm{a}} \\
\$ 42,000 \\
\mathrm{BS}^{\mathrm{b}} \\
\$ 11,000\end{array}$ & $\begin{array}{c}\text { BRC } \\
\$ 42,000 \\
\text { IT } \\
\$ 95,000 \\
\mathrm{RWH}^{\mathrm{c}} \\
\$ 19,000 \\
\end{array}$ \\
\hline $\begin{array}{c}\text { Estimated } \\
\text { Annual } \\
\text { Maintenance } \\
\text { Cost }\end{array}$ & - & $\$ 5,000$ & $\begin{array}{c}\text { BRC } \\
\$ 6,000 \\
\text { BS } \\
\$ 600\end{array}$ & $\begin{array}{c}\text { BRC } \\
\$ 6,000 \\
\text { IT } \\
\$ 5,000 \\
\text { RWH } \\
\$ 1000 \\
\end{array}$ \\
\hline $\begin{array}{l}\text { Total } \\
\text { Cost }\end{array}$ & - & $\$ 101,000$ & $\$ 50,000$ & $\$ 168,000$ \\
\hline
\end{tabular}

*Total Runoff in a 25 -year rainfall event, unit: $\mathrm{m}^{3}$

**Peak Rate in a 25 -year rainfall event, unit: $\mathrm{m}^{3} / \mathrm{s}$

${ }^{a}$ BRC - Bioretention Cell

${ }^{\mathrm{b}} \mathrm{BS}$ - Bioswale

${ }^{c}$ RWH - Rainwater Harvesting

The above analysis showed that LID Option \#2 had the best performance in terms of reducing total runoff and peak rate for all rainfall events. However, the total construction cost and the annual maintenance fees were 
the highest for this option. LID Option \#1 was the cheapest, but it did not meet the design requirements The conventional design was cheaper than the LID \#2 design, but the 25-year rainfall event peak rate was much higher than the design specification.

\section{Conclusions}

This paper analyzed different designs for a newly developed neighborhood. A conventional design included less common green space and had no room for additional lots, moreover, it had the potential for flooding.

LID Option \#1 (with bioretention cells and bioswales) was the cheapest, but it did not meet project goals; total runoff was $5,550 \mathrm{~m}^{3}$ greater than the target and peak rate flow was greater than the target by $0.3 \mathrm{~m}^{3} / \mathrm{s}$. LID Option \#2 (with bioretention cells, infiltration trench, rainwater harvesting) was the most expensive option, but it met all target requirements.

This study indicated that LID designs were more effective in reducing peak rate than a conventional design. A dry detention pond reduced total runoff efficiency, while an infiltration trench reduced total runoff and peak rate better than a bioswale.

\section{Acknowledgements}

This project was supported by the National Key Research and Development Program of China (2016YFC0402404) and the Special Fund of State Key Laboratory of Simulation and Regulation of a Water Cycle in a River Basin, China Institute of Water Resources and Hydropower Research (SKL2018TS08). The article was also supported by the National Natural Science Foundation of China (41701322, 41501299).

\section{References}

1. D.B. Jennings, S.T. Jarnagin. Changes in Anthropogenic Impervious Surfaces, Precipitation and Daily Streamflow Discharge: A Historical Perspective in A Mid-Atlantic Subwatershed. Landscape Ecol. 17, 471-489 (2002).

2. B. Ye, D. Sheng, X. Men. Causes and Countermeasures of Urban Water Logging. J. Econ. Water Resources. 28, 62-65 (2010).

3. E. Kuichling. The Relation between the Rainfall and the Discharge of Sewers in Populous Districts. Tran. ASCE. 20, 1-56 (1889).

4. B.K. Ferguson, P.W. Suckling. Changing Rainfall runoff Relationships in the Urbanizing Peachteree Creek Watershed, Atlanta, Georgia. J. the AWRA. 26, 313-322(1990).

5. R. Pitt, S. Clark, R. Field. Groundwater Contamination Potential from Stormwater Infiltration Practices. Urban Water J. 1, 217-236 (1999).
6. EPA, U.S. Low Impact Development (LID): A Literature Review. In: EPA-841-B-00-005, U.S. EPA. (2000).

7. R. Pitt. Unique Features of the Source Loading and Management Model (SLAMM). Adv. Modelling Man. of Stormwater Impacts. 6, 13-37 (1997).

8. A. Elliott, S. Trowsdale. A Review of Models for Low Impact Urban Stormwater Drainage. Env. Modelling \& SW. 22, 394-405 (2007).

9. B.J. Barfield, J. Hayes, S. Harp, K. Holbrook, J. Gillespie. IDEAL: Integrated Design and Evaluation Assessment of Loadings Model. Watershed Models. 361-380 (2005). 